FINANCIAL: Jurnal Akuntansi

Published by Program Studi Akuntansi STIE Sultan Agung Volume 7-Nomor 2, Desember 2021, (HIm 207-223)

ISSN-P: 2502-4574, ISSN-E: 2686-2581

Available online at: https://financial.ac.id/index.php/financial

\title{
THE EFFECT OF NON PERFORMING LOAN, CAPITAL ADEQUACY RATIO AND INCOME SMOOTHING ON LOAN LOSS PROVISION WITH RESTRUCTURING POLICY AS MODERATE VARIABLES
}

\author{
Oryza Sativa Heningtyas ${ }^{1)}$, Atik Isniawati ${ }^{2)^{*}}$, Veronica Tri Astuti ${ }^{3)}$ \\ ${ }^{1,2,3}$ Faculty of Economics, Department of Accounting, Darma Persada University, Jl. Taman Malaka \\ Selatan No.8, RW.6, Pd. Klp., Kec. Duren Sawit, Kota Jakarta Timur, Daerah Khusus Ibukota Jakarta \\ 13450, Indonesia \\ Email: ${ }^{1}$ heningtyas302@gmail.com, ${ }^{2}$ aisniawati@gmail.com, ${ }^{3}$ veronicatriastuti17@gmail.com
}

*Penulis Korespondensi

\begin{abstract}
This study wants to examine the effect of NPL on LLP, CAR on LLP, EBTP on LLP moderated by restructuring policies before and after the Covid-19 pandemic. Of these three variables have similarities that have a direct or indirect impact on the performance and capacity of bank debtors. This impact has the potential to disrupt banking performance, which turns out to be changing and disrupts financial system stability which has an impact on Indonesia's economic growth due to the Covid-19 pandemic. This study uses secondary data, the sample selection method used in this study is purposive sampling method with a sample of 55 companies and 1100 observation data. This type of research is quantitative research, data analysis using multiple linear regression and group moderation test. These findings indicate that the NPL and income smoothing variable has a significant positive effect on LLP. From the results of the study, it can be concluded that banks in Indonesia increase LLP when the NPL increases as an effort to mitigate the risk of loss.CAR has an insignificant negative effect on LLP which indicates the absence of capital management. The results of the EBTP and LLP tests have a significant positive effect, it can be concluded that there is an indication of income smoothing (IS) activity in conventional banking in Indonesia. Meanwhile, policy restructuring is not able to moderate the relationship between NPL, CAR, Income Smoothing and LLP.

Keywords: NPL, CAR, Income Smoothing, LLP, Restructuring Policy
\end{abstract}

Article History: Received: 1 Okt 2021 Revised: 21 Nov 2021 Accepted: 27 Nov 2021 


\section{INTRODUCTION}

Banks can manage credit risk in maintaining business continuity so that the potential for losses can be minimized. In this regard, credit risk management must be carried out effectively, including maintaining asset quality and establishing adequate allowance for possible losses.

The activity of the bank itself is to collect funds from the public and then channel the funds back to the community through credit, in the process of running the credit, the bank has the potential to experience losses which have an impact on the decline in the value of an asset. Impairment is a condition in which there is objective evidence of a loss event occurring as a result of one or more events that occurred after the initial recognition of the credit, and that loss event has an impact on the estimated future cash flows of a financial asset or group of financial assets that can be reliably estimated. reliable as stated in Bank Indonesia Regulation Number 14/15/PBI/2012.

To anticipate these risks, banks are required to establish and set aside funds to cover the risk of losses on loans extended to customers. In the Indonesian banking regulations, which are made referring to PSAK 50 and 55 to overcome the risk of credit losses that occur due to the possibility of the counterparty (counterparty) failing to meet maturing obligations, or the risk of loss due to the borrower not being able to repay all or part of his debt, the bank must determine Loan Loss Provision (LLP). (Fitriana \& Arfianto, 2015).

Factors that can affect LLP include NPL (Aristei \& Gallo, 2018; Beatty \& Liao, 2020; Kim et al., 2019; Ozili, 2020; Peterson K. Ozili, 2017; Soedarmono et al., 2017; Tao, 2020). In addition, the influence of
CAR on LLP indicates the occurrence of capital management (Abu-serdaneh \& Abuserdaneh, 2018; Beatty \& Liao, 2020; Elnahass et al., 2018; Peterson K. Ozili, 2017). And income smoothing describes the relationship between earning before tax \& provision and LLP which indicates earnings management.against LLP which indicates earnings management (Aristei \& Gallo, 2018; Elnahass et al., 2018; Kim et al., 2019; Ozili \& Outa, 2017; Simper et al., 2019; Soedarmono et al., 2017).

The income smoothing hypothesis examines the relationship between LLP and earnings before taxes and provision.Iit is used that banks will use LLP to smooth profits so that profits appear stable (Ozili \& Outa, 2017).

In conventional banking in Indonesia for the 2016-2019 period, LLP always decreases every year, but has increased in the 2020 period, which is thought to be due to the Covid-19 pandemic. Data on Allowance for Impairment Losses at Conventional Banks can be seen in table 1 below:

Table 1. Data on Average LLP at Conventional Commercial Banks for the 2016-2020 period (in percentage)

\begin{tabular}{|c|c|c|c|c|c|}
\hline Year & 2016 & 2017 & 2018 & 2019 & 2020 \\
\hline LLP (\%) & 3,97 & 3,76 & 3,40 & 2,88 & 5,36 \\
\hline
\end{tabular}

Source: Bank Indonesia (2021)

From Table 1, it can be seen that the number of LLP always decreases. However, the amount of LLP for five consecutive years is not in accordance with what is determined by Bank Indonesia, which is at least $1 \%$. For this reason, it is necessary to have a clearer analysis of the factors that have caused the amount of LLP not to reach the limit set by Bank Indonesia. The purpose of this study is to determine the effect of NPL on LLP in 
banking companies registered with the OJK, to determine the effect of CAR on LLP in banking companies registered at the OJK, to determine the effect of IS on LLP in banking companies registered at the OJK. On the moderating variable, To find out whether the Restructuring Policy moderates the effect of NPL on LLP in Banking Companies Registered with the OJK, To find out whether the Credit Restructuring Policy moderates the effect of CAR on LLP in Banking Companies Registered at the OJK, To find out whether the Credit Restructuring Policy moderates the effect of Income Smoothing against LLP in Banking Companies Registered at OJK.

Based on the literature review above, this study wants to examine the effect of NPL on LLP, CAR on LLP, Income Smoothing on LLP moderated by restructuring policies before and after the Covid-19 pandemic. Of these three variables have similarities that have a direct or indirect impact on the performance and capacity of bank debtors. This impact has the potential to disrupt banking performance, which turns out to be changing and disrupts financial system stability which has an impact on Indonesia's economic growth due to the Covid-19 pandemic.

\section{LITERATURE REVIEW}

The theoretical basis discusses the basic theory used, namely signal theory. Hypothesis development discusses the basis for formulating hypotheses derived from theory, previous research and explanations that are relevant to the proposed hypothesis. Finally, conceptual framework that provides an overview of the logic of thinking on the basis of the theory used. The theoretical study in this research is Signal Theory which explains that the information (news) conveyed by the company is good news and bad news (Cheung et al., 2014). Signal theory is used to describe the behavior of both parties who have different access to information. One party called the signaler (signaler) must examine which signal will be informed. On the other hand, the signal receiver (receiver) must be more careful how to interpret the signal because the signal given is positive and some is negative.

Hypothesis development discusses the basis for formulating hypotheses derived from theory, previous research and explanations that are relevant to the proposed hypothesis. Finally, a conceptual framework that provides an overview of the logic of thinking on the basis of the theory used. The theoretical study in this research is Signal Theory which explains that the information (news) conveyed by the company is good news and bad news (Cheung et al., 2014). Signal theory is used to describe the behavior of both parties who have different access to information. One party called the signaler (signaler) must examine which signal will be informed. On the other hand, the signal receiver (receiver) must be more careful how to interpret the signal because the signal given is positive and some is negative.

In this study, banks capture signals from loan loss provisions (LLP) and credit risk. It is used by bank managers to smooth out earnings, because lower income volatility tends to send a positive signal to investors that bank risk remains manageable. Changes in credit risk that are expected to occur become important information for banks to manage credit distribution so that the collectability of defaulted loans can be avoided. The signal theory relationship can be used as a basis for decision making for banks if there are positive signals that can make it easier for banks to determine the 
estimated loan loss reserves so that credit risk can be minimized (Elnahass et al., 2018).

In the signaling hypothesis, LLP is used as a tool to signal that the company is ready to face the worst conditions in the future (Aristei \& Gallo, 2018). Companies that give positive signals can attract investors and outsiders to invest in the company (Fitriana \& Arfianto, 2015). A signal is an action taken by the company's management that provides clues to investors about how management views the company's prospects (Ghozali 2016).

Napisah (2020) the relationship between signal theory and this research is used as a basis for decision making for investors and creditors and explains how a company provides positive and negative signals to users of financial statements. Companies that give positive signals can attract the attention of outside parties and investors in deciding to invest in companies that have financial performance information. The amount of Loan Loss Provision or LLP is a signal of the financial strength of the bank where the signal is represented by profit.

\section{Loan Loss Provision (LLP)}

Loan Loss Provision (LLP) is a reserve created by banks to cover the risk of losses on the credit portfolio that will occur in the future for their funding that is impaired in the credit quality assessment). LLP is a solution for banks to face the risks that banks will face or as a prudent banking principle (Heningtyas \& Widagdo, 2019).

With the revision of PSAK 55 in 2006, the term PPAP (Product Asset Losses) was replaced by Loan Loss Provision (LLP) or what is often referred to as Loan Loss Provision (LLP). Based on the collectibility level of credit, the PBI Regulation concerning LLP Bank Indonesia (PBI No. 14/15/PBI/2012) with the following provisions: 1) General Reserves is Current Category Credit $<1 \%$. 2) The Special Reserve is divided into 4 (four) sections: a) $5 \% \mathrm{x}$ category credit in special mention; b) $15 \% \times$ (substandard credit - collateral value); c) $50 \% \times$ (doubtful credit category collateral value); and d) $100 \%$ x (bad credit category - collateral value).

In the formation of LLP, it is assessed from the results of the debtor credit evaluation conducted by the bank. If a bank has objective evidence that the credit of the debtor has decreased, then the bank must establish funds or reserves for the credit. Because the results of the debtor's credit evaluation are based on the decisions of each bank, each bank has its own policy in establishing reserves for its credit (Fitriana \& Arfianto, 2015). If the bank does not have LLP, the bank is unable to anticipate the risk of loss of productive assets because this is one of the factors causing the bank to experience a financial crisis (Permatasari, 2020).

When compared to the method of establishing funds according to PPAP and LLP, it can be seen that the PPAP calculation is simpler than the calculation of LLP, because it only takes into account the allowance for funds based on the level of credit collectibility of the debtor, while for the calculation of LLP, it is necessary to look at one by one whether the debtor's credit is is disturbed or not. After that, it will only form a reserve fund after there is evidence that the debtor's credit is impaired (Ldr \& Setiatin, 2020).

The method of establishing LLP is by checking one by one debtor's credit so that credit control becomes more focused, so that if there is an impairment, the bank will 
immediately find a way out so that the debtor's credit does not harm the bank. Therefore, with this LLP calculation, at least banks can reduce the occurrence of credit risk that they will experience, so that it will improve banking health (Fitriana \& Arfianto, 2015).

\section{Non-Performing Loan (NPL)}

In providing credit to customers, banks will be faced with credit risk that debtors cannot afford to pay, causing non-performing loans. Banks determine credit quality as regulated by the OJK Regulation (Financial Services Authority) in POJK RI No. 40/POJK.03/2019 concerning Assessment of Commercial Bank Asset Quality dated December 19, 2019.Based on the description of the credit quality assessment, it is determined to be: 1) Smooth there are no arrears in principal or interest payments on loans; 2) In special attention there are arrears in payment of principal or interest on credit for up to 90 days; 3) Not Smooth is a statement if There are arrears in payment of principal or interest on credit for up to 120 days; 4) Doubful is a statement if There are arrears in payment of principal or credit interest up to 180 days. And the last 5) Jams is a statement if The debtor is no longer able to pay the principal or interest on the loan and an appeal will be made by the bank with the debtor.

NPL is non-current non-performing loans or loans where the debtor does not meet the agreed requirements. In reality, not all loans disbursed are risk-free, some of which have a large enough risk and can threaten the health of the bank (Elnahass et al., 2018). NPL is a condition where the debtor is unable to pay all or part of the customer's obligations to the bank, namely the obligation to pay the installments that Copyright (C) 2021, FINANCIAL: Jurnal Akuntansi have been promised at the beginning. This credit risk is defined as the risk associated with the client's possible failure to pay his obligations or the risk that the debtor cannot pay off his debts (Ldr \& Setiatin, 2020).

According to Peterson K. Ozili (2017), this ratio indicates that the higher the NPL ratio, the worse the credit quality. The Bank conducts review and binding of collateral to minimize credit risk. Bank Indonesia stipulates the safe limit of NPL in a bank's non-performing loan ratio should not exceed 5\%. Non-performing loans are loans that have non-current or substandard quality, where the total credit is calculated based on the balance sheet which has not been calculated grossly with LLP (Napisah, 2020).

\section{Capital Adequacy Ratio (CAR)}

Capital Adequacy Ratio (CAR) also known as KPMM (Minimum Capital Adequacy Ratio) is a capital ratio that shows the bank's ability to provide funds for business development purposes and accommodate the risk of loss of funds caused by bank operations (Fitriana \& Arfianto, 2015). The motivation for capital management through LLP can be associated with incentives to increase or maintain capital adequacy to avoid official capital costs if the bank's regulatory capital ratio is below the minimum regulatory requirements (Elnahass et al., 2018). The motivation for using LLP can be used for capital purposes because banks with low capital can build higher LLP for that by increasing LLP will increase the capital adequacy ratio. (Abuserdaneh \& Abu-serdaneh, 2018; Elnahass et al., 2018).

According to Maulidiyah (2017) found that credit risk can also explain the relationship between CAR and LLP because the higher the CAR ratio means the more 
adequate capital is compared to Risk Weighted Assets (RWA) so this indicates that there is capital management. The calculation of CAR in Indonesia is adjusted to the Decree of the Board of Directors of BI No.26/20/Kep/DIR and SE BI No.26/2/BPPP. The regulation stipulates that the minimum capital adequacy for banks is measured from a certain percentage of riskweighted assets, which is $8 \%$.

\section{Income Smoothing (IS)}

The attention of investors who are often only profit-centred makes him oblivious to the procedures used to generate earnings information. This matter encourage managers to perform earnings management or manipulation of earnings. One of them is with Income Smoothing (IS) or profit before tax and reserves is the ability of a bank to generate profit from its operational activities. This study uses the Income Smoothing (IS) variable which is a proxy for earnings management because low earnings for the current period motivate managers to reduce LLP, thereby artificially increasing profits, when a higher current profit rate provides motivation for managers to increase LLP(Aristei \& Gallo, 2018; Elnahass et al., 2018; Ozili \& Outa, 2017).

According to research (Aristei \& Gallo, 2018), banks use LLP for earnings management, the aim is to manage bank income and stabilize income flows from time to time which states that the level of risk is high, the lower income for that banks have lower incentives by using LLP for earnings management purposes.

Some literature discusses earnings management and LLP in the banking industry. (Elnahass et al., 2018) stated that the motivation for using LLP for earnings management is that bank managers can Copyright (C) 2021, FINANCIAL: Jurnal Akuntansi provide additional LLP for loan loss reserves in the expansion period and smoothen income in the recession period to reduce the volatility of reported earnings.

\section{Restructuring Policy}

Credit restructuring is a bank program as a repair and rescue effort carried out in credit activities for debtors who have difficulty fulfilling their obligations so that banks do not experience losses caused by non-performing loans (Disemadi \& Salih, 2020). Credit restructuring is carried out, among others, through 1) Lower lending rates; 2) Adding credit period; 3) Stop credit interest arrears and the last 4) Stop credit principal arrears.

According to Pernando (2020) credit restructuring programs have generally been widely applied in the banking world. Where, the bank that disburses credit has a restructuring program that is regulated in the credit policy of each bank. The purpose of credit restructuring is to provide credit relaxation to affected businesses through various restructuring schemes such as extending credit tenors or loan terms, reducing interest rates (decreasing), reducing principal arrears (cut loss), reducing interest arrears, adding credit facilities for businessmen.

The Financial Services Authority (OJK) issued POJK regulation No. 11/POJK.03/2020 concerning National Economic Stimulus as a Contracyclical Policy stipulates that debtors or owners of credit obligations who receive special treatment in the POJK are debtors (including MSMEs) who have difficulty fulfilling obligations to banks (OJK) (OJK, 2020b). This is because debtors are affected by the spread of COVID-19 either directly or indirectly in the economic sector, such as 
tourism, transportation, hospitality, trade, processing, agriculture, and mining. Because of this, banks can restructure all loans/financing to all debtors affected by COVID-19 (Pernando, 2020). OJK policies during the Covid-19 pandemic are regulated in OJK Regulation No. 11 of 2020.

Effect of Non-Performing Loans on Allowance for Impairment Losses

Non-Performing Loan (NPL) is a condition in which the debtor is unable to repay its obligations to the bank as measured by the ratio of non-performing loans to total loans. This ratio indicates that the higher the NPL ratio, the worse the quality of bank credit. This credit quality includes three categories, namely substandard loans, doubtful loans and bad loans (Kim et al., 2019)

According to (Ozili \& Outa, 2017) states that the relationship between NPL and LLP has a significant positive effect. In mitigating credit risk, banks will set aside higher funds if the debtor's non-performing loans are high to estimate loan losses that occur in the bank's credit portfolio.

In line with research (Aristei \& Gallo, 2018) which states that NPL has a significant positive effect on LLP. Banks will increase efforts to back up their funds when nonperforming loans increase in order to cover the risk of credit losses that are estimated to be higher. Research conducted by (Tao, 2020) found that there was a positive relationship between NPL and LLP. This shows that if a bank has high non-performing loans, the bank will increase more reserves in order to prevent future risks.

The research results of Nichols et al. (2009) also support this finding by proving the positive influence of NPL on LLP. This indicates the timely recognition of LLP which is directly proportional to the NPL and is controlled by credit write-off (WO). This means that banks that recognize LLP more timely and followed by the realization of credit write-offs are more conservative banks. However, Beatty \& Liao (2011) provide contradictory empirical evidence, namely the negative and significant effect of NPL on LLP which reflects the delay (untimely) of LLP recognition. Wheeler (2019) supports this finding and states that the less conservative recognition of LLP by banks is due to pro-cyclical behavior which causes banks to delay the recognition of credit losses at the beginning of the crisis so that "unrecognized overhangs" will form. This less conservative behavior will be able to increase the information asymmetry between management and stakeholders so that it will further worsen the company's performance (Isniawati et al., 2018). The longer the crisis lasts, banks are forced to admit losses incurred). This is getting bigger because banks are no longer able to hide credit losses with their capital, this is because it is difficult for them to get capital from outside as the crisis worsens (Wheeler, 2019).

H1: NPL has a positive effect on LLP

\section{Effect of Capital Adequacy Ratio on Allowance for Impairment Losses}

Capital Adequacy Ratio (CAR) is a capital ratio that shows a bank's ability to provide funds in managing capital as measured by the ratio of its own capital including core capital (Tier 1 capital) plus supplementary capital (Tier 2 capital) divided by risk-weighted assets (RWA. Tier capital). 1 includes paid-in capital, while Tier 2 capital includes subordinated bonds with a minimum remaining term of five years. Capital management is an attempt by 
company managers to regulate and manipulate their capital adequacy which describes a series of relationships between CAR and LLP (Ozili \& Outa, 2017).

Research conducted by (Ozili \& Outa, 2017) shows a negative relationship between CAR and LLP which states that when bank capital is low, banks will set aside high fund reserves for capital management purposes. This resulted in a decrease in the ability of banks to channel credit so that in the end the bank lost its ability to generate optimum profit from its operational activities.

In research (Abu-serdaneh \& Abuserdaneh, 2018; Ozili \& Outa, 2017; Ozili, 2015) tested the capital management hypothesis by using the relationship between the capital adequacy ratio (CAR) to LLP which shows that if bank managers have low regulatory capital, then bank managers have an incentive to increase LLP to meet the capital ratio requirements.

H2: CAR has a positive effect on LLP

\section{Effect of Income Smoothing on Loan Loss Provision}

Income Smoothing is a proxy ratio in measuring earnings management, which is one way for banks to manage income by generating profits from their operational activities as measured by net operating profit before tax and bank reserves divided by total assets. The higher the income smoothing, the greater the company's ability to earn profits so that the bank's operational activities can run well.

Research conducted by Ozili (2016) which states that there is a positive and significant relationship between IS and LLP. This shows that due to an increase in income income smoothing it will be followed by an increase in loan loss reserves formed by banks. This is in line with research Copyright (C) 2021, FINANCIAL: Jurnal Akuntansi
(Soedarmono et al., 2017) which shows a positive relationship between income smoothing and LLP. Whereas bank managers carry out earnings management by forming reserves to facilitate income driven by income smoothing.

H3: Income Smoothing has a positive effect on LLP

\section{Restructuring Policy Moderates the Effect of NPL on LLP}

The banking sector must anticipate the potential for NPL. One way is that the banking sector must increase the Loan Loss Provision (LLP). LLP is a cushion owned by the banking sector to deal with customers who were unsuccessful in credit restructuring during the POJK No. 11 Year 2020 ends. The goal is to anticipate potential increases in NPL, not to improve NPL (Bisnis Indonesia, 23 November 2020).

Supported by research by Bushman \& Williams (2019) which proves that the influence of credit restructuring policies strengthens NPL on LLP. This implies that when the bank takes more risk, the loan loss provision is increased because the bank allows restructuring when the debtor is unable to repay the loan and is required to be granted concessions in the form of an extension of the loan term or an interest waiver for a certain period of time.

The low NPL value during 2020 shows that the credit restructuring policy carried out by the OJK can run effectively because many bank customers have received credit restructuring for this reason, banks make reserves for restructured non-performing assets. As a result, many debtors whose credit status is still considered smooth in paying their obligations. This means that the credit restructuring policy strengthens the 
relationship between NPL and LLP (Boy \& De Nicolo 2017).

H4: Restructuring Policy strengthens the relationship between NPL and LLP

\section{Restructuring Policy Moderates the Effect of CAR on LLP}

Restructuring policies make banks hold less money. This is because loans that should have matured this year, debtors can delay payments due to this policy. One of the factors that indicate that the restructuring policy is CAR (Capital Adequacy Ratio) (Disemadi \& Shaleh, 2020)

According to research conducted by (Bawa et al., 2019; Fiordelisi \& Fofack, 2016) stated that credit restructuring policies weaken capital management in banks that restructured assets are so detrimental that they can translate into significant capital implications for the government which has a majority of lenders. . For that, banks need to set aside a large portion of the money for bad loans. That when banks have high capital, banks tend to take higher risks because of the accumulated amount of restructured assets.

H5: Restructuring policy weakens the relationship between CAR and LLP

\section{Restructuring Policy Moderates the Effect of Income Smoothing on LLP}

The success rate of a bank compared to other banks can be seen from how much profit the bank earns. To get the maximum profit, the bank tries to minimize the burden and improve the quality of service so as to get a large income. The largest bank income comes from debtor interest income on loans. However, when debtors have difficulty paying off their loans, interest income is threatened to decline. If this condition drags on, banks will experience a crisis that could have an impact on the global economy (Bawa et al., 2019).

This is supported by (Aktiva et al., 2020) which states that there is a credit restructuring policy that weakens the relationship between restructured assets and profits. This implies that the bank has asset quality that is unlikely to generate income in the form of interest and principal payments. Based on the description above, the proposed hypothesis is:

H6: Restructuring policy weakens the relationship between CAR and LLP

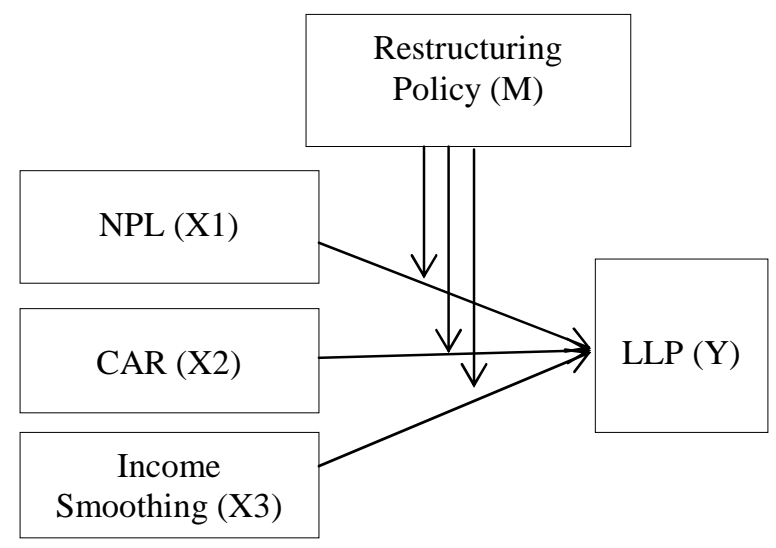

Figure 1.

Relationship Model between Variables

\section{METHODS}

The method used in this study is a quantitative method. The data used in this research is secondary data. The secondary data in this study was obtained by the author in the form of documentation of the annual financial statements of conventional commercial banks registered with the Financial Services Authority (OJK) in the 2016-2020 period through www.ojk.go.id. This research was processed using SPSS 25.

\section{Population and Sample}

The population of this study are banking companies registered with the Financial Services Authority and publishing financial reports for the 2016-2020 period in 
the form of quarterly. The data used in this research is secondary data. The sampling method used is purposive sampling with the following criteria: A banking company registered with the Financial Services Authority (OJK) and issuing quarterly financial reports available on the OJK or the company's website for 2016-2020 and Banking companies that have complete financial information and data relating to the variables to be studied for the 2016-2020 period.

\section{Data Collection Technique}

The data collection technique used purposive sampling technique, which means selecting the object of research with predetermined criteria.

\section{Data Analysis Technique}

The data analysis technique used multiple linear regression and group moderation test to determine the difference in the effect of the independent variable on the dependent variable before and after the issuance of the restructuring policy, the analytical tool used SPSS version 25 . The analysis used in this research is multiple regression analysis, which is to see the effect of NPL, CAR, Income Smoothing on LLP. The regression model used Multiple Regression Analysis can be formulated with the following equation:

$$
\mathrm{LLP}=\alpha+\beta 1 \mathrm{NPL}+\beta 2 \mathrm{CAR}+\beta 3 \mathrm{IS}+\mathrm{e}
$$

\section{RESULTS AND DISCUSSION}

The study was conducted on banking companies registered with the Financial Services Authority and published quarterly financial reports for the 2016-2020 period. Based on the research criteria, 55 banks were obtained with a total of 1100 observations registered with the OJK as follows:

Copyright (C) 2021, FINANCIAL: Jurnal Akuntansi
Table 2. Sample Selection

\begin{tabular}{|c|l|c|}
\hline No. & \multicolumn{1}{|c|}{ Sample Criteria } & Amount \\
\hline 1. & $\begin{array}{l}\text { Banking Companies } \\
\text { registered with the } \\
\text { Financial }\end{array}$ & 115 \\
$\begin{array}{l}\text { Authority (OJK) forvices } \\
\text { 2016-2020 period }\end{array}$ & \\
\hline 2. & $\begin{array}{l}\text { Banking companies that } \\
\text { do not publish quarterly } \\
\text { financial reports in a row } \\
\text { and whose financial } \\
\text { statements are incomplete } \\
\text { in the 2016-2020 period }\end{array}$ & $(13)$ \\
\hline 3. & $\begin{array}{l}\text { Banking companies that } \\
\text { do not have complete } \\
\text { financial information and } \\
\text { data relating to the } \\
\text { variables to be studied } \\
\text { such as NPL CAR, } \\
\text { EBTP against LLP for } \\
\text { the 2016-2020 period. }\end{array}$ & $(47)$ \\
\hline Total Companies (Sample) & 55 \\
\hline Total Research Observation & 1100 \\
Data (55x4) x 5 years & \\
\hline
\end{tabular}

Source: Processed Data (2021)

\section{Descriptive Statistics}

Based on the results of descriptive statistics, it is known that the data from this research is limited only to companies that meet the criteria listed at the OJK in 20162020 which are presented in millions of rupiah. The total sample processed in this study was 55 banks with a total of 1100 observations. Descriptive statistics provide a description of each variable seen from the number of observations of the minimum value, maximum value, mean, and standard deviation. The results of descriptive analysis using SPSS 25 the results of descriptive statistical data are presented in the table below: 
Table 3. Descriptive Statistics Results

\begin{tabular}{llllll}
\hline & $\mathrm{N}$ & Min. & Max. & Mean & $\begin{array}{l}\text { Std. } \\
\text { Deviation }\end{array}$ \\
\hline $\mathrm{NPL}$ & 1100 & .0003 & .3070 & .0331 & .0224 \\
$\mathrm{CAR}$ & 1100 & .0150 & .9462 & .2396 & .1175 \\
$\mathrm{IS}$ & 1100 & .0018 & 182.8 & .1637 & .1346 \\
$\mathrm{CKPN}$ & 1100 & .0001 & .0970 & .0192 & .0141 \\
Valid & 1100 & & & & \\
$\mathrm{~N}$ & & & & & \\
\hline
\end{tabular}

Source: Processed Data SPSS 25 (2021)

The results of the dependent variable LLP in data observations have a minimum value of 0.00010 , a maximum value of 0.09700 , an average value of 0.0192657 and the standard deviation value obtained is 0.01410861. This means that the LLP variable indicates that the bank has a high LLP as seen from the average value obtained at 0.0192657 . The non-performing loan (NPL) variable for observation data has a minimum value of 0.00030 , a maximum value of 0.30700 , an average value of 0.331500 and a standard deviation of 0.2245628 . Based on the average value obtained of 0.331500 , it shows that banking companies have a high level of nonperforming loans of $33.1 \%$.

The results of the variable Capital Adequacy Ratio (CAR) in the observation data have a minimum value of 0.01500 , a maximum value of 0.94620 , an average value of 0.2396996 and a standard deviation of 0.11750743 . Based on the average value obtained of 0.2396996 , it shows that banking companies have a high level of capital adequacy. Furthermore, the results of the IS variable for observation data have a minimum value of 0.00181 , a maximum value of 1.82847, an average value of 0.1637543 and a standard deviation of 0.13469123 . Based on the average value obtained is 0.1637543 , indicating that the company has a high profit.

\section{Hypothesis Test Results}

This study aims to determine the significant effect of each independent variable on the effect of the dependent variable being tested. If the significant value $>0.05$ then the null hypothesis (H0) is accepted and (Ha) is rejected, so it is not significant. If the significant value is $<0.05$ then the null hypothesis (H0) is rejected and (Ha), so it is significant (Ghozali, 2018).

In this hypothesis test, group moderation is moderated by the restructuring policy variable as measured by a dummy variable where the value is 0 for banking companies before the issuance of restructuring policies, and 1 for banking companies after the issuance of restructuring policies. In this test, 3 tests were carried out with 3 equations, namely, equation 1 without moderation, equation 2 before the issuance of the restructuring policy for the 2016-2019 period, and equation 3 after the issuance of the restructuring policy for the 2020 period. As follows:

Table 4. Non-Performing Loan (NPL), Capital Adequacy Ratio (CAR), Income Smoothing (IS)

\begin{tabular}{|c|c|c|c|}
\hline $\begin{array}{c}\text { Variabel } \\
\text { Period }\end{array}$ & $\begin{array}{c}1 \\
2016- \\
2020\end{array}$ & $\begin{array}{c}2 \\
2016- \\
2019\end{array}$ & $\begin{array}{c}3 \\
2020-\text { After } \\
\text { Restructuring } \\
\text { Policy }\end{array}$ \\
\hline \multirow[t]{2}{*}{$\mathrm{C}$} & 0.000 & 0.000 & 0.000 \\
\hline & 14.154 & 6.634 & 4.810 \\
\hline \multirow[t]{2}{*}{ NPL } & 0.000 & 0.000 & 0.000 \\
\hline & 4.444 & 4.934 & 3.537 \\
\hline \multirow[t]{2}{*}{ CAR } & 0.537 & 0.501 & 0.223 \\
\hline & $(0.618)$ & $(0.673)$ & -1.223 \\
\hline \multirow[t]{2}{*}{ IS } & 0.000 & 0.000 & 0.000 \\
\hline & 5.103 & 3.121 & 2.444 \\
\hline $\begin{array}{l}\text { Adjusted } \\
\text { R Square }\end{array}$ & 1.430 & 0.151 & 0.144 \\
\hline
\end{tabular}

Source: Processed Data SPSS 25 (2021) 
Effect of Non-Performing Loan on Allowance for Impairment Losses

Hypothesis 1 examines the effect of NPL on LLP. In table 4 the results of the first hypothesis test indicate that there is a positive and significant effect between NPL on LLP, marked by the magnitude of tcount for the NPL variable of 4.444 which is positive with t-table of 1.96213 or it can be said that the value of t-count $>\mathrm{t}$-table and a significance value of 0.000 which the value is less than the probability value of 0.050 . Thus, these results indicate that there is a positive and significant effect between nonperforming loans on the allowance for impairment losses, so $\mathrm{H} 1$ is accepted.

In table 4 these results show that NPL has a positive and significant effect on LLP. This means that if the NPL increases, the bank will increase LLP. The results of this study are consistent with (Ozili \& Outa, 2017; Ozili (2016); Ozili (2019) which states that banks will tend to increase LLP if there is an indication of an increase in default. This is done so that banks can anticipate the risk of loss. According to PBI Regulations No.14/15/PBI/2012 indicators in the formation of LLP are seen from the risk of non-performing loans at a bank. The bank will evaluate the funds given to the debtor whether there is objective evidence of the debtor having defaulted. So the bank will decide whether it is necessary to establish funds to be reserved .

Based on the study of financial stability by Bank Indonesia (2021), there was a decrease in credit decline from 2016-2020 and an increase in NPL in 2016-2020 at Indonesian conventional commercial banks. At this time, Indonesian conventional commercial banks tend to lead to pro-cyclical behavior. This means that when the economy worsens, LLP increases due to the emergence of rising NPL so that bank lending slows down. With the slowing pace of credit growth, it is difficult to expect economic growth to move in a positive direction. With the tendency of excessive procyclicality, a countercyclical policy is needed that can encourage the rate of credit distribution (CNBC Indonesia, 2020).

\section{Effect of Capital Adequacy Ratio on Allowance for Impairment Losses}

Hypothesis 2 examines the effect of CAR on LLP. In table 4 the results of the second hypothesis test show that there is a negative but not significant effect between CAR on LLP, marked by the magnitude of tcount for the CAR variable of -0.618 which is negative with t-table of 1.96213 or it can be said that the value of t-count $<\mathrm{t}$-table and a significance value of 0.537 whose value is greater than the probability value of 0.050 . This indicates that there is no capital management in conventional commercial banks in Indonesia. Thus, these results indicate that there is a negative and insignificant effect between CAR and LLP, so $\mathrm{H} 2$ is rejected.

In table 4 these results show that CAR has a negative and insignificant effect on LLP. This shows that the level of CAR does not affect the amount of LLP determined by the bank. The results of this study indicate that conventional commercial banks in Indonesia do not carry out capital management because capital management through LLP is reflected in the insignificant negative relationship between CAR and LLP.

The findings in this study are consistent with research (Ozili \& Outa, 2017) which states that banks use LLP to manage regulatory capital requirements. This is because the regulator requires banks to maintain minimum regulations for risks taken 
by including LLP in the Tier 2 capital component. Motivation of bank managers to avoid capital adequacy costs below the minimum capital adequacy requirements.

\section{Effect of Income Smoothing on Loan Loss Provision}

Hypothesis 3 examines the effect of Income Smoothing on LLP. In table 4, the results of the third hypothesis test show that there is a positive and significant effect between IS on, marked by the magnitude of tcount for the IS variable of 5.103 or it can be said that the value of tcount $>\mathrm{t}$-table and a significance value of 0.000 which is smaller than the probability value of 0.050 . This indicates the occurrence of earnings management using IS in conventional commercial banks in Indonesia. Thus, these results indicate that there is a positive and significant effect between IS on LLP, so H3 is accepted.

In table 4 these results show that IS has a positive and significant effect on LLP. This means that the higher the IS, the higher the LLP. The results of this study indicate the occurrence of earnings management using LLP in conventional commercial banks in Indonesia. Thus, this is done to anticipate losses if at any time the company's profits decline.

This finding is in line with the results of research conducted by Ozili, (2016). stated that there is a positive relationship between IS and LLP. That is, if the profit increases, the loan loss reserves formed by the bank also increase. This indicates the occurrence of earnings management by using LLP which aims to reduce the volatility of reported earnings.

Copyright (C) 2021, FINANCIAL: Jurnal Akuntansi

\section{Restructuring Policy Moderates the Effect of NPL on LLP}

Hypothesis 4 examines the effect of NPL on LLP with restructuring policy as a moderating variable. This study uses a group moderation test which aims to examine the difference in the effect of NPL on LLP before and after the issuance of the restructuring policy. Table 4 shows that there is no difference in the results of the effect of NPL on LLP before and after Restructuring Policy because both have significant values. The results of this test are indicated by the same significance value and direction between the two before and after Restructuring Policy of $0.000<0.050$. Thus, this shows that the restructuring policy does not moderate the relationship between NPL and LLP, so H4 is rejected.

Based on the results of the difference test, table 4 shows that the credit restructuring policy does not moderate the relationship between NPL and LLP. These results indicate that there is no difference in the effect of NPL on LLP before and after the issuance of the restructuring policy because both of them show significant positive results. Thus, the results of the study show that there is no difference before and after the restructuring policy because the new regulations were implemented in the 1 st quarter of 2020 and this research period is only until 2020, so the results are not yet visible. The results of this study are consistent with research conducted by Boy \& De Nicolo (2017) which states that the banking sector must anticipate the potential for NPL by increasing LLP to deal with debtors who cannot repay loans and are required to be given leeway in the form of credit restructuring that has been determined. by OJK in the form of extending loan terms, reducing interest rates, reducing principal 
arrears in accordance with bank analysis (Novianggie \& Airlangga, 2021).

\section{Restructuring Policy Moderates the Effect of CAR on LLP}

Hypothesis 5 examines the effect of CAR on LLP with restructuring policy as a moderating variable. This study uses a group moderation test which aims to examine the difference in the effect of CAR on LLP before and after the issuance of the restructuring policy. Table 4 shows that there is no difference in the results of the effect of CAR on LLP before and after Restructuring Policy because both have significant values. The results of this test are indicated by the same significance value and direction between the two, namely a value of 0.000 for before KR and a value of 0.015 for after Restructuring Policy, so both have a significance value less than 0.050 . Thus, this shows that the restructuring policy does not moderate the relationship between CAR and LLP, so H5 is rejected.

Based on the test results, table 4 shows that the restructuring policy does not moderate the relationship between CAR and LLP. These results indicate that there is no difference in the effect of CAR on LLP before and after the issuance of the restructuring policy so that both show significant negative results. Thus, the restructuring policy does not affect the capital management carried out by conventional commercial banks in Indonesia. Capital management practices are not found in conventional commercial banks in Indonesia, presumably due to the implementation of Basel II. At this time Basel II takes effect, LLP is included in the Tier 2 capital component and is calculated at a maximum of $100 \%$ of the RWA. The implementation of Basel II requires banks to increase their capital ratios when facing greater risks. Therefore, after the entry into force of Basel II, it will hinder the occurrence of capital management which indicates that conventional commercial banks in Indonesia do not carry out capital management (Ozili \& Outa, 2017).

\section{Restructuring Policy Moderates the Effect of Income Smoothing on LLP}

Hypothesis 6 examines the effect of IS on LLP with restructuring policy as a moderating variable. This study uses a group moderation test which aims to examine the differences in the effect of IS on LLP before and after the issuance of the restructuring policy. Table 4 shows that there is no difference in the results of the effect of IS on LLP before and after Restructuring Policy because both have insignificant values. The results of this test are indicated by the same significance value and direction between the two, namely a value of 0.501 for before Restructuring Policy and a value of 0.223 for after Restructuring Policy, then both have a significance value greater than 0.050 . Thus, this shows that the restructuring policy does not moderate the relationship between CAR and LLP, so H6 is rejected.

Based on the test results in table 4 , it shows that the restructuring policy does not moderate the effect of IS on LLP. The results of this study indicate that there is no difference in earnings management carried out by conventional commercial banks in Indonesia before and after the issuance of the restructuring policy. Banks in Indonesia lead to pro-cyclical behavior, as evidenced by the findings at Bank Indonesia, which is authorized to regulate and supervise macroprudential policies in Indonesia. Macroprudential policies are more focused on the behavior of financial institutions that 
tend to be procyclical (CNBC Indonesia, 2020). Procyclical behavior means that when the economy improves, the number of nonperforming loans is a little so that the LLP is low, so credit distribution is excessive. With the restructuring policy, which aims to make conventional commercial banks in Indonesia change their behavior into a countercyclical one. Banks do more earnings management using a credit risk approach. Contracyclical behavior can be interpreted that when the economy improves, the bank sets a high LLP (Trinova, 2018).

\section{CONCLUSION}

Based on the results of data analysis that has been tested and carried out several analyzes, the results of research based on the formulation of the problem can be concluded as follows NPL has a positive and significant influence on LLP in banking companies registered with OJK in 2016-2020. This shows that if the NPL increases, then the bank tends to increase LLP. This is done so that the bank can mitigate the risk of loss. Banks increase CKPN when bad loans increase is one of the bank's efforts to mitigate the risk of loss.

CAR has a negative but not significant effect on LLP in banking companies registered with OJK in 2016-2020. This shows that the level of CAR does not affect the amount of LLP determined by the bank. This indicates that there is no capital management in conventional commercial banks in Indonesia. The positive influence between EBTP and LLP also indicates income smoothing (IS) activity in conventional banking in Indonesia.

Income Smoothing has a significant positive effect on LLP in banking companies registered with the OJK in 2016-2020. This shows that when the profit earned by the bank is high, the bank tends to reserve higher funds. This is done in order to anticipate losses if at any time the company's profits decline because the reserves are used to increase profits when the company's profits decline drastically.

Restructuring policy does not moderates the influence of NPL on LLP in banking companies registered with OJK in 2016-2020. These results indicate that there is no difference in the effect of NPL on LLP before and after the issuance of the restructuring policy because both of them show significant positive results.

The Restructuring Policy does not moderate the effect of CAR on LLP in banking companies registered with OJK in 2016-2020. These results indicate that there is no difference in the effect of CAR on LLP before and after the issuance of the restructuring policy so that both show significant negative results.

The Restructuring Policy does not moderate the effect of Income Smoothing on LLP in banking companies registered with OJK in 2016-2020. The results of this study indicate that there is no difference in earnings management carried out by conventional commercial banks in Indonesia before and after the issuance of the restructuring policy.

\section{SUGGESTION}

Suggestions for future researchers are to test the impact of implementing restructuring policies for a longer period of time. This research time span is limited to 5 years. The results of the moderation of the restructuring policy are not yet clear because the regulation was implemented in the first quarter of 2020. For this reason, the research year period can be studied longer in order to influence the results of the study. The researcher also provides suggestions for 
further researchers to review the economic stimulus policies in Indonesia based on POJK 11 of 2020. This policy is a government step to overcome economic problems due to the impact of the COVID-19 pandemic.

\section{REFERENCES}

Abu-serdaneh, J., \& Abu-serdaneh, J. (2018). Bank loan-loss accounts, income smoothing , capital management, signaling and procyclicality Evidence from Jordan. https://doi.org/10.1108/JFRA-06-20160041

Aktiva, J., Akuntansi, R., Keuangan, D. A. N., Dasan, P. T., Indonesia, P., Indonesia, P. T. P., Paiho, P. T., Abstrak, I., Indonesia, B. E., \& Banking, P. A. (2020). Analisa Perpanjangan Restrukturisasi Kredit Terhadap Likuiditas Perbankan Sebelum dan Sesudah Pandemi Covid 19. 2(3), 37-45.

Aristei, D., \& Gallo, M. (2018). AC. International Review of Economics and Finance.

https://doi.org/10.1016/j.iref.2018.10.02 2

Asworo. (2020). Keringanan Kredit Karena Corona ini 8 Syarat yang Wajib Dipenuhi. Retrieved from Retrived https://finansial.bisnis.com/read/20200 326/90/1218473/keringanan-kreditkarena-corona-ini-8-syarat-yang-wajibdiketahui.

Bawa, J. K., Basu, S., \& Basu, S. (2019). Jurnal Pra-bukti. 0-31. https://doi.org/10.1016/j.iimb.2019.10.0 09

Beatty, A., \& Liao, S. (2020). Alternative evidence and views on asymmetric loan loss provisioning. Journal of Accounting and Economics, xxxx, 101362. https://doi.org/10.1016/j.jacceco.2020.1 01362

Boy, \& Nicolo. (2017). Teori pengambilan risiko bank dan persaingan ditinjau kembali. Jurnal Keuangan, 60 (3), , 1329-1343.

Bushman, \& Williams. (2012). Kebijaksanaan akuntansi, provisi kerugian pinjaman, dan disiplin pengambilan risiko bank. urnal Akuntansi dan Ekonomi, 54 (1) , 1-18.

Cheung, Y.-L. (2014). The signaling effect of corporate social responsibility in emerging economies. Springer Science+Business Media Dordrecht, 113. https://doi.org/10.1007/s10551014-2404-4, 289-312.

Disemadi, H. S., \& Shaleh, A. I. (2020). Banking credit restructuring policy on the impact of COVID-19 spread in indonesia Research Method. 05(02), 63-70.

Elnahass, M., Izzeldin, M., \& Steele, G. (2018). Capital and Earnings Management : Evidence from Alternative Banking Business Models. International Journal of Accounting, $x x x x$, $1-13$. https://doi.org/10.1016/j.intacc.2018.02. 002

Fitriana, M. E., \& Arfianto, E. D. (2015). ANALISIS PENGARUH NPL , CAR, ROA , LDR DAN SIZE TERHADAP CKPN ( Studi Kasus pada Bank Konvensional yang Tercatat di Bursa Efek Indonesia 2010-2014 ). 4, 1-8.

Heningtyas, O. S., \& Widagdo, A. K. (2019). Bank loan loss provisions research: A review of the empirical literature. 23(2), 270-282.

Kim, J., Kim, M., \& Hwan, J. (2019). The effect of TARP on loan loss provisions and bank transparency. Journal of Banking and Finance, 102, 79-99. https://doi.org/10.1016/j.jbankfin.2019.0 3.006

Ldr, P., \& Setiatin, T. (2020). Pengaruh LDR dan NPL terhadap CKPN. 6(3), 27-37.

Maulidiyah. (2017). Pengaruh NPL, CAR, dan LDR terhadap Cadangan Kerugian Penurunan Pengaruh NPL, CAR, dan LDR terhadap Cadangan Kerugian Penurunan 2011-2015. Jurnal Riset 
Akuntansi, http://eprints.perbanas.ac.id/id/eprint/27 92.

Novianggie, V., \& Airlangga, U. (2021). Optimalisasi restrukturisasi kredit sebagai relaksasi kredit pelaku umkm pada masa pandemi corona 1. 2(2), 65-70.

Ozili, P. K. (2020). Bank loan loss provisioning during election years: cross-country evidence. 16(4), 413-431. https://doi.org/10.1108/IJMF-09-20190317

Ozili, P. K., \& Outa, E. (2017). Borsa _ Istanbul Review Bank loan loss provisions research: A review. Borsa Istanbul

Review. https://doi.org/10.1016/j.bir.2017.05.00 1

P, I. D., \& Indriani, A. (2016). ANALISIS FAKTOR-FAKTOR $Y A N G$ BERPENGARUH TERHADAP LOAN LOSS PROVISIONS ( Studi pada Bank Konvensional yang Terdaftar di Direktori Perbankan Indonesia Periode 2011-2015 ). 5(2011), 1-12.

Permatasari, I. (2020). Does corporate governance affect bank risk management? Case study of Indonesian banks. https://doi.org/10.1108/ITPD-052020-0063

Pernando. (2020). Keringan kredit melalui restrukturisasi dilakukan,fasilitas kredit serta konversi utang. Retrieved from Retrieved from https://finansial.bisnis.com/read/202004 14/90/1227121/restrukturisasi- kreditini-4-hal-yang-mesti-dipertimbangkansebelum-minta-keringanancicilan\#: :text=Keringan kredit melalui restrukturisasi dilakukan,fasilitas kredit serta konversi.

Peterson K. Ozili. (2017). No Title. Journal Istanbul Review, 1-20. https://doi.org/http://dx.doi.org/10.1016/ j.bir.2017.05.001

Simper, R., Dadoukis, A., \& Bryce, C. (2019). European bank loan loss provisioning and efficient technological innovative progress. International
Review of Financial Analysis, \#pagerange\#.

https://doi.org/10.1016/j.irfa.2019.03.00 1

Soedarmono, W., Eko, S., \& Tarazi, A. (2017). Research in International Business and Finance The procyclicality of loan loss provisions in Islamic banks ๕. Research in International Business and Finance, 39, 911-919. https://doi.org/10.1016/j.ribaf.2016.05.0 03

Tao, Y. (2020). China's anti-corruption campaign and bank loan loss provisions: Evidence from a quasinatural experiment sis. Economics Letters, 109505. https://doi.org/10.1016/j.econlet.2020.1 09505 